\title{
STATE ECONOMIC DEVELOPMENT POLICY AND THE POLITICAL PROCESS
}

\author{
Eugene A. Laurent and Harry W. Miley, Jr.*
}

Man's response to things he does not understand generally involves myth and ritual. For example, early man's understanding of natural forces such as volcanoes and hurricanes was slight. He responded with very detailed theories about angry gods with hammers and severe stomach disorders. Among the rituals intended to soothe the divine tummies were tribal dancing and the sacrifice of chickens.

Today, we understand natural phenomenons a little better. We don't dismember many chickens. However, myth still reins in many areas of human endeavor and ritual response continues to operate. In particular, state economic development policy is a good example of ritual and less-than-rational behavior. Examples of development rituals are widespread. They range from annual "business climate" surveys to detailed tabulations of state economic policies. Often we have little understanding, if any, of the relationship between the rituals and economic development.

Business climate studies, for example, are seldom analyzed to determine the applicability or the relative importance of variables to a specific state or industry. Yet, business climate studies have become an important issue in campaigns for state office. As a result, concern over "business climate" (whatever that means) strongly affects policy making in South Carolina and many other states in fields ranging from higher education to welfare.

Perhaps the most entertaining ritual involves the annual migration of Chamber of Commerce and business and trade associations to the state capitol in search of additional tax subsides. They attempt to show why the state is suddenly in danger of losing jobs to other more attractive areas. Every year they claim that disaster looms and the spectre of unemployment will march across the land. Such rituals continue to prove relatively successful in the almost complete absence of independent evidence that state taxes play a major role in guiding business location decisions. [See for example: Morgan and Hackbart (1974), Rinehart (1963), Schemenner (1979), Ross (1953), Hekman (1982), Dorf and Emerson (1978) and Fortune (1977)].

Nonetheless, it does appear that we all believe in economic development. All fifty states have some type of office or agency whose primary responsibility is promoting economic development. Although titles and responsibilities may vary, the agencies share one primary goal: to foster the growth and development of their state's economy. Generally the agency directly responsible for industrial development is also responsible for economic development.

Unfortunately, states seldom define economic development policy in very rigorous terms. An old management axiom states: "If you don't know where you are going, any road will take you there." State development strategies are often developed in this manner. They come into being incremently over time without any underlying economic theory except more jobs are good and less jobs are bad. This lack of definition results in considerable pressure on state leaders to adopt each and every development policy that has been adopted by nearby states. Indeed, Malizis and Reid argue that public policy has been improperly conceived and emphasize that one of the reasons is present "theoretical perspectives on regional development policy" (Malizia and Reid, p. 41).

Having said all of the foregoing, where does this leave state economic development policy? In attempting to answer this question, we made a brief review of the literature. It is obvious from even a cursory glance at the literature that the states are currently a hotbed of new initiatives to support

*Deputy Executive Director, State of South Carolina Budget and Control Board and Associate Director, Division of Research, College of Business Administration, University of South Carolina 
economic development. (While we knew this was true in South Carolina, we had not realized the extent of activity in other states, such as, Pennsylvania, Rhode Island, New York, etc.). Many of the states have task forces, studies and so on to deal "with the challenges of the 1980s." Quite frankly, from what we have read, most states are still gearing up to meet the challenges of the 70s-uneven development, plant closings, lower levels of capital investment. (This is not meant as a criticism because many states were hit with severe economic disruptions that they do not want to face again.) But if we remove the verbage, there is question as to how far we are looking ahead.

In attacking these problems, state efforts can be broken into two categories. There are what we might call traditional industrial development and another we might call state economic development policy approach. These are familiar concepts and will be only briefly defined here.

Traditional industrial development emphasizes state programs that provide high scores in business climate rankings. This includes such things as low business taxes, site preparation, and industrial recruiting. Subsidies to industries generally come from the tax system in terms of property tax exemptions, inventory exemptions, etc. and not from state appropriated dollars. State dollars are concentrated primarily on industrial recruitment and advertising. This approach places importance on fiscal responsibility and how traditional government functions (highway, education, and environmental protection) are handled.

Recently, the traditional industrial development approach has recognized that not all businesses in an economy play the same role in economic development. Efforts have begun to do some industry targeting. High tech is presently a buzz word in targeting. In South Carolina, we define any industry that will be with us five years from now as high tech. However, in general, the traditional approach is an attempt to provide a favorable economic climate for all types of industries.

The second approach generally means relatively more state involvement with appropriated dollars to support economic development. This approach involves such items as venture capital investments, development of research parks, job development banks, and so forth, instead of a package of general incentives. Obviously, it is difficult to draw a fine line between these approaches and of course, some states pursue both policies. However, there are several important points involving the approaches.

First, it should be no surprise that it is difficult to sway the state power structure away from the traditional approach. Not only are they very familiar with it, but in the short run, it's cheap. It does not require the expenditure of large amounts of state dollars. By controlling regulations, having task forces to coordinate agency activities and information, or providing small changes in the tax laws, an apparently positive development program can be presented. Most importantly this creates a development program that does not require a direct outlay of state funds. Any attempt to redirect state policy is not really an argument over economic theory, but rather an argument to redirect state dollars.

The second point is that economic development is a long-term phenomenon, but at the state level it tends to be viewed as a short-run process. Most "development" programs are short-run in nature (for example: tax-holidays and credits, job programs). This may be a result of misguided policymakers, but in most cases is not. It is much more likely that the relatively short terms of office inherent in our political system tend to lead to rather short-run "development" programs. Our political system with politicians serving for a short term of office just does not lend itself to long-term policies. As a result, our economic development policies tend to be somewhat myopic in nature.

A third point is that both the traditional and the new approaches to development make the same assumption that economic development is an absolute good-that increasing the number of jobs will improve the standard of living for everyone. Yet, we know this is not so. We know economic development has an uneven impact on any economic system. Many people involved in State government have been attempting to have the adverse impact recognized in state policy for at least 10 years with absolutely no success. Again, this difficulty is not surprising if you look carefully at the development process.

The economic activities that benefit from economic development have four basic characteristics:

- a market that is inherently local

- little or no ability to move

- a costs structure well below the revenues resulting from expected markets

- and of course, anyone owning or dealing in land. (State Policy Reports, 1984) 
What type of firms do these characteristics cover: accountants, attorneys, newspapers, construction, radio and TV, real estate, lumber yards, and department stores. In addition, gas and electric utilities generally see themselves as beneficiaries of growth. In general, this list is the who's who of local area or state. Any dismantling of traditional policies often threatens this group and results in serious opposition to any redirecting of state dollars.

On the other side of the coin, not everyone gains from economic growth. Rising property values drive up apartment and housing rents as well as warehouse and commercial rents. Developing areas may pull the able and educated from one area to another causing serious disruptions in communities, government services, etc. Existing industry may experience upward pressures on wages which can force industry to substitute capital for labor thus hurting the employees that are terminated. It is important to remember that the negative aspects of development are also an inherent part of the state's approach to development. As such, negative benefits should be explicity recognized in state policy. However, it is difficult to accomplish.

Another concept that is difficult to get state policymakers to deal with is the issue of "People vs. Place" prosperity. In most introductory classes on regional economics, the first classroom discussion involves whether people should have to move to jobs or should jobs be brought to people. We have not made much progress on this issue over the years. Most states have made this decision without discussion and by default. Most states attempt to bring jobs to political subdivisions.

We have already discussed part of the reason for this inertia. The "Place Prosperity" approach is nonselective. Employment gains and increased incomes will occur in part to those that need it. However, a large portion of the benefits will accrue to those who need it the least. This tends to create a large constituency. But more importantly, it leads to some interesting policy.

In South Carolina, for example, in an effort to aid the unemployed, we give special assistance to economic activities in the nine poorest counties. These counties contain roughly 17,000 unemployed workers. On the other hand, the nine urban counties contain about 75,000 unemployed, but we provide no special assistance. The problem is that "place distress" and "people distress" do not necessarily coincide geographically.

In the beginning of this discussion, I mentioned the axiom that "if you don't know where you are going, any road will take you there." We probably should modify this to read "if you don't know where you are going, any road will take you there, but it may not be where you want to be."

This is a pretty fair summary of past state development efforts. The only way to deal with the types of nagging questions mentioned here, as well as others, is to introduce at the upper levels of the state bureaucracy some of the rigor we have indicated was missing. That is, a state must have agreed upon and defined goals for development policy. The state will have to make some difficult decisions in setting those goals. For example, how is the state going to resolve the "place" or "people" conflict? Is the state going to take care of those left behind by its other development efforts and if so, how? These and many other questions must be addressed in order to formulate state development goals.

Perhaps as important as these questions and goals is that these goals must have success criteria tied to them. In order to monitor and measure a program's progress and success, there must be a set of success criteria.

As Bartels et al. (1982) point out, "the purpose of policy evaluation is to acquire insight into the consequences that are attributed to certain policies." But as Hareman (1976) and Schofield (1979) have stated, it is not quite so simple to evaluate policies since the impacts of regional economic policy may be evaluated from several perspectives. They agree that policy may be evaluated from: first, its impact on the regional distribution of goal variables such as economic welfare, economic activities and labor market discrepancies; secondly, its contribution to goal variables of national policy, such as national output and full employment; and thirdly, the financial impact on the treasury, which is of special interest to policymakers who have to choose among alternative uses of scarce resources. The first perspective has been the one most frequently used by policy evaluators. The selection of the perspective is an important first step in the evaluation procedure, since this selection determines the variables on which policy assessment will focus. Otherwise, there is no mechanism for dealing with special interest in the allocation of state dollars. There is no way to determine the benefits and costs of alternative programs, and there is no mechanism for instituting sound management practices. 


\section{REFERENCES}

Bartels, C.P.A., W.R. Nicol, J.J. Van Duijn, "Estimating the Impact of Regional Policy," Regional Science and Urban Studies, Vol. 12, (1982), pp. 3-41.

Dorf, Ronald J. and M. Jarvin Emerson, "Determinants of Manufacturing Plant Location for Nonmetropolitan Communities in the West North Central Regional of the U.S.," Journal of Regional Science, Vol. 18, No. 1, 1978, pp. $109-120$.

Fortune Magaizine Survey, 1977.

Hekman, John S., "Survey of Location Decisions in the South," Federal Reserve Board Economic Review, June 1982 , pp. 6-19.

Malizia, E. and D. Reid, "Perspectives and Strategies for U.S. Regional Development," Growth and Change, October 1976.

Morgan, William E. and Merlin M. Hackbart, "An Analysis of State and Local Industrial Exemption Programs," Southern Economic Journal, October, 1974, pp. 200-205.

Rinehart, James R., "Rates of Return on Municipal Subsidies to Industry," Southern Economic Journal, April, 1963 , pp. 297-306.

Ross, William D., "Tax Exemption in Louisiana as a Device for Encouraging Industrial Development," Southwestern Social Science Quarterly, June, 1953, 14-22.

Schemenner, Roger, "Look Beyond the Obvious in Plant Location," Harvard Business Review, Vol. 57, Vol. 1, (January/February, 1979), pp. 130-132.

State Policy Reports, March, 1984. 